\title{
A mulher como intelectual pública ${ }^{1}$ Women as public intellectuals
}

\author{
MARTA NUNES DA COSTA ${ }^{2}$
}

A presença das mulheres na Filosofia se tem tornado tópico de inquérito e preocupação na academia brasileira nos últimos anos. Isso se deve, parcialmente, à tentativa e esforços conjuntos de várias professoras, filósofas e acadêmicas de problematizar a condição feminina enquanto espaço que tem sido, ao longo da história, problematizado. O direito das mulheres, inclusive das mulheres filósofas, se constrói hoje a partir do desvelamento da lógica que suportou a invisibilidade e estratégias de invisibilização históricas - não só teóricas, mas sentidas na carne, nos corpos.

A partir de um trabalho iniciado no livro Ensaios no Feminino, publicado em 2018, procuro, neste artigo, dar continuidade a uma reflexão acerca dos lugares que as mulheres ocupam ou não ocupam, assim como tentar compreender a relação das duas ordens: a ordem da justificação (nomeadamente, na história da filosofia em geral, mas mais precisamente, via uma leitura crítica da história da filosofia política) e a ordem da legitimidade. Ora, o conceito de legitimidade tornou-se central para pensar as democracias contemporâneas. Por isso, pensar o lugar das mulheres não é apenas uma missão teórica, mas uma missão enraizada no compromisso de viver em democracia - a inclusão ou exclusão das mulheres nos diferentes espaços deve ser legítima, isto é, devem ser dadas boas razões aceites por 'todos' de forma a não invalidar as promessas democráticas da igualdade e liberdade.

A estas duas ordens, porém, que refletem duas promessas (da razão/igualdade e da liberdade) devemos acrescentar uma terceira - a promessa da fraternidade. E aqui o nosso problema torna-se incontornável, ou melhor dizendo, se as promessas da igualdade e liberdade pareciam garantir uma 'neutralidade' (de género), a promessa da fraternidade impõe violentamente a lógica da dominação masculina - a fraternidade, onde a liberdade e igualdade se manifestam, é de e para homens; o que significa dizer que na origem da concepção democrática (moderna) de liberdade e igualdade está a consolidação de uma lógica patriarcal que naturaliza, ainda mais, a desigualdade de género. Dito ainda por outras palavras, a liberdade e igualdade são possíveis apenas na medida em que se constroem sobre a exclusão do outro, a saber, sobre a exclusão da mulher. Exclusão, entretanto, em que sentido? De onde? De que espaço? Do espaço do visível, do espaço público. Reparem: o que torna público esse

\footnotetext{
${ }^{1}$ Este texto foi apresentado no III Encontro Mulheres E Filosofia, realizado na UFMS nos dias 17 e 18 de maio de 2018.

${ }^{2}$ Professora adjunta de Filosofia na UFMS; Professora Permanente do PPG de Filosofia da UNIOESTE; coordenadora do Grupo de Estudos Democráticos (CNPQ): www.estudosdemocraticos.com.br. E-mail: nunesdacosta77@gmail.com.
} 
espaço é a premissa de que algo ou alguém pode nele aparecer, enquanto outros devem ficar de fora. A noção de 'espaço público' foi construída sobre o seu 'outro', o 'espaço privado', ocupado exclusivamente por mulheres.

Daqui não é difícil dar os passos seguintes, e desvelar toda uma lógica que nos acompanha até hoje, quer seja pelo viés de uma análise do 'capitalismo', quer seja pelo viés de uma análise do 'patriarcado'. Esta última permite reconstruir as origens de um discurso (religioso) até à secularização das práticas em que as mulheres devem naturalmente obediência aos homens. A primeira, a análise do capitalismo, permite compreender como o próprio modo de produção capitalista só se pode consolidar tendo já naturalizado a lógica patriarcal, sendo sobre ela que se consolida igualmente a distinção esfera pública/esfera privada. A esfera pública é a esfera do homem, do trabalho fora de casa, onde o valor é produzido e reproduzido. A esfera privada, é a esfera da mulher, de dentro de casa, que não tem valor (e valor é sempre valor social) aparente. Porém, isso é apenas aparência pois sem esse trabalho tornado sem valor (dentro de casa) não seria sequer possível o trabalho no espaço público. Ou seja, o trabalho invisível das mulheres é condição necessária ao sistema capitalista.

Expliquei no livro Ensaios no Feminino as nuances e evolução dos conceitos e relações entre visibilidade/invisibilidade, capitalismo e patriarcado. Aqui, quero explicar como cheguei ao tema de hoje.

Se o espaço público é tradicionalmente ocupado por homens, isso reflete-se no nosso aparato teórico e no nosso olhar: o que tem valor está fora; esse fora é ocupado por homens; homens têm (mais) valor; as mulheres não têm (tanto) valor; e mesmo quando aparecem no público a sua presença é desvalorizada, o seu valor é desigual.

Esta crença, este dogma, esta leitura estereotipada da realidade atua sem darmos por isso. Olhemos em nossa volta: quantas mulheres na esfera pública são 'referência' nos nossos debates, nas nossas reflexões, no nosso diálogo? Quem faz a mediação entre o nosso pensamento e o pensamento dos outros? Ou se quiserem, pensem por outro ângulo: a própria noção de 'intelectual público'. Esta noção, embora seja em teoria neutra quanto à questão de género, é na prática aplicada a um papel desempenhado predominantemente por homens, de forma a que a história das mulheres enquanto intelectuais tende a permanecer desvalorizada. Esta desvalorização - enquanto processo ativo - traduz-se numa discriminação institucionalizada (do qual a academia não é exceção) o que explica, pelo menos em parte, os contra-movimentos considerados 'feministas' (e entendo aqui feminismo no sentido de uma ideologia que advoga uma igualdade radical entre os sexos).

Então, o que significa ser um 'intelectual público'? O dicionário dá-nos uma primeira resposta: "um intelectual que expressa posições (especialmente em tópicos 
populares' com intenção de que estas sejam acessíveis a uma audiência geral". Mas será que isto é tão óbvio? Afinal o que significa hoje ser 'intelectual'? Será que ser 'intelectual' significa ter uma profissão relacionada ao intelecto, à academia? $\mathrm{O}$ intelectual é aquele que busca conhecimento? De que forma, e em que sentido? Quem se dedica à pesquisa científica deve automaticamente ser considerado intelectual público? Ou essa 'descrição' tem um domínio mais vasto? Será que o intelectual público se define pelo pensamento crítico? E se for pelo pensamento crítico, pode / deve não ser limitado pela ocupação / profissão que ocupa, isto é, podemos ter intelectuais públicos no meio da academia mas também de outras áreas? O 'intelectual público’ é aquele que tem domínio específico da sua própria área, isto é, ele é um 'especialista'? Sendo especialista, como pensamos a hierarquia dentro do exercício da sua função? Precisamos agora dar mais atenção ao termo 'público' - o que este 'público' significa? Significa falar, dirigir-se fisicamente para um público? Mas então, qualquer pessoa que fale em público exerce o papel de intelectual público? Se assim fosse, todos os professores seriam naturalmente intelectuais públicos, mas sabemos que não é o caso. Então, será que não tem apenas a ver com o público ao qual o discurso se dirige, mas também o 'tema' tratado e a forma de tratamento que lhe é dada? O intelectual público fala de que lugar? De um lugar público ou privado, de uma universidade pública ou de uma instituição privada?

A estas podemos acrescentar um número vasto de outras questões: qual a relação entre o intelectual público, a verdade e o conhecimento? Ele/ela falam de um lugar privilegiado? Quais as suas características, como o classificar?

Vejam que há diferentes possibilidades: podemos pensar no intelectual público como especialista; como crítico, como aquele que denuncia o que está errado, como astro 'pop' que contribui para a divulgação de 'conhecimentos', mas devemos incluir hoje o papel das redes sociais, pois elas transformaram significativamente a 'esfera pública'. A esfera pública constrói-se a partir de dentro; ela não reside apenas no 'fora' tradicional (pensemos que Habermas falava dos jornais e revistas como meio original que constituiu a própria definição desse espaço, no século XIX). A cisão entre detentores dos meios de comunicação e consumidores de comunicação também está fragmentada. Não entrarei nas implicações de todos estes aspectos; o meu propósito era mais modesto, apenas mostrar a complexidade de uma expressão, de um termo, que geralmente tomamos como 'óbvio'.

Se olharmos como na história este conceito/ categoria vem sido exemplificada, vemos que a maioria dos exemplos são de homens. Isso encontra explicação nas naturalizações históricas e internalizações de desigualdades socialmente construídas. Mas então, como nos posicionamos hoje em relação a mulheres que ocupam esse espaço público? Ou seja, o que eu quero que façam é que olhem para o modo como recebem as informações, as críticas, os conteúdos? Esse modo varia caso 
seja homem ou mulher? Se sim, por que será que isso acontece? E como transformar?

Quero dar-vos apenas dois exemplos. O primeiro, Olympe de Gouges e Mary Wollstonecraft. Olympe de Gouges escreve a Declaração dos Direitos da Mulher e da Cidadã (1791) como resposta à Declaração dos Direitos do Homem e do Cidadão (1789). Mary Wollstonecraft escreve Reivindicação dos Direitos da Mulher (1792). Ambas as autoras, contemporâneas da Revolução Francesa, podem ser vistas como intelectuais públicas: elas 'entram' na 'esfera pública' da sua época, escrevendo panfletos ou livros - as suas posições são divulgadas amplamente no meio por elas frequentadas. Ambas partem do pressuposto iluminista do 'direito natural'; ambas denunciam a contradição de promover um discurso de igualdade e liberdade à conta da exclusão de metade do género humano. Elas fazem-no de forma clara; elas dão argumentos e mostram como o discurso universalista está condenado se perpetuar a lógica da dominação. Mas mais do que isso. Elas afirmam-se como exemplos de algo muito mais forte e mais fundamental: elas reivindicam o próprio direito de existir de existir publicamente. $\mathrm{O}$ ethos da mulher é por isso diferente do ethos do homem. O homem fala e é ouvido; o homem fala porque ele já existe, isto é, ele já é reconhecido como homem, i.e, como igual e livre, detentor do direito de aparecer (isto é, do direito de ser para os outros); a mulher não. $\mathrm{O}$ direito à existência não é dado anteriormente; ele é criado pelo ato da fala e da escrita; à mulher não lhe é dado o direito de falar, de participar, de existir politicamente - o que é no mínimo curioso o fato de que no contexto revolucionário francês, as mulheres terem sido proibidas de participar politicamente, ao mesmo tempo que a figura que representa, visível e simbolicamente a liberdade, é a figura da mulher (representação nos quadros, nos panfletos, etc.). Retomo, porque à mulher não lhe é reconhecido esse direito (que seria um direito natural), ela deve conquistá-lo pelo ato de se recriar, como sujeito/ sujeita, a partir da palavra. $\mathrm{O}$ ato da escrita torna-se ato existencial, de afirmação do eu; a criação de uma voz que insistiam em negar, abafar, suprimir, matar, silenciar. E esse ato revolucionário de existência para os outros a partir da escrita conviveu de forma flagrante com a negação dos direitos universais, que estavam sendo proclamados, de cidadania. A mulher não era cidadã; à mulher não lhe foi concedido o direito de construir o novo mundo da igualdade. Sobre a mulher foi construída a promessa de uma igualdade eternamente desigual, pelo menos enquanto durar a própria ideologia da qual é refém. Mary Wollstonecraft e Olympe de Gouges cumpriram o seu destino como intelectuais públicas - elas reivindicaram o seu lugar na história, na história revolucionária, na história do pensamento, na história e percurso sentido das mulheres. Elas denunciaram o erro da narrativa iluminista e rousseauniana; elas denunciaram a injustiça da desigualdade de género e da desigualdade racial (ambas estavam comprometidas com a abolição da escravatura), elas denunciaram os limites da Razão e do próprio projeto de esclarecimento humano. 
16o anos mais tarde escreve Simone de Beauvoir O Segundo Sexo. Também ela se afirmou como intelectual pública - e a sua obra é marco exatamente porque obrigou a romper, e rompeu de fato, com a hegemonia do discurso masculino. Mas Beauvoir fez mais do que isso: ela obrigou à revisão das nossas convicções mais profundas e ao confronto com os nossos preconceitos mais naturais. Ela foi intelectual pública exatamente porque ela se mostrou pela escrita a um público e contribuiu para a criação de uma pauta que antes não existia. Até hoje trabalhamos no horizonte dessa pauta desenhada por ela.

Poderia acrescentar uma outra referência, a saber, Hannah Arendt. Arendt é sem dúvida um exemplo de uma intelectual pública, mulher; mas ela é mais do que isso - ela dá-nos não só uma 'crítica da condição presente' como sobretudo um novo meio para pensar em conjunto. Como? Subvertendo, transformando as categorias tradicionais da teoria política. A sua escrita, que é ao mesmo tempo cativante e perturbadora (porque nos faz navegar pela própria experiência do pensamento sem necessariamente se cristalizar e sem se deixar sistematizar) pode ser interpretada como um convite - um convite a pensar em conjunto. É isso, afinal, que nos distingue de todos os outros seres vivos: o juízo enquanto capacidade de pensar com os outros, um pensamento que é necessariamente inseparável da presença dos outros.

Os exemplos foram breves, mas quero terminar com uma reflexão.

As quatro mulheres pensadoras, autoras, intelectuais públicas que mencionei partilham de uma perspectiva que as torna intelectuais públicas: 1. Todas têm conhecimento 'teórico'; 2 . Todas têm conhecimento prático (i.e., sentem na pele); 3. Todas pensam criticamente, i.e., os seus textos revelam uma crítica bem fundamentada da 'ordem' dominante na qual se inserem; 3. Todas escrevem na intenção de transformar o que é, fazendo do texto um instrumento de denúncia e combate à injustiça. De onde falam? De um lugar que sim, partilha, a ideologia dominante; porém, elas criticam essa mesma ideologia, mesmo sem a querer (ou poder) superar.

E hoje? Qual o papel do intelectual público, mas mais precisamente, qual o papel da mulher como intelectual pública? Que papel pode ter a mulher como intelectual pública no Brasil?

A resposta deve ser dada por partes. Em relação à primeira, é preciso perceber que só há intelectuais públicos e públicas se, e enquanto, houver público - não apenas um público receptor/passivo, mas um público engajado, um público leitor. Habermas, numa entrevista recente ${ }^{3}$ disse que hoje nos deparamos com inúmeros obstáculos para que esse 'espaço' de troca possa efetivamente existir. Por um lado, temos o problema da privatização dos meios de comunicação e tudo o que isso

\footnotetext{
${ }^{3}$ Ver https://elpais.com/elpais/2018/o5/o7/inenglish/1525683618_14576o.html
} 
implica (Brasil e EUA são exemplos chocantes desse fenómeno); por outro, o problema da mercantilização visível na internet, para não falar de um outro fenômeno que é as fake News. Neste contexto, aquele ou aquela que se candidata a desempenhar este papel - de intelectual pública - não terá um percurso fácil, a não ser que ceda aos 'avanços' e imperativos capitalistas, liquidando a própria promessa que $o$ ato encerra em si.

Ora, para uma mulher a tarefa é ainda mais difícil - por ser mulher, sem dúvida. Mas também pela tarefa implicada: não basta hoje 'falar' em tom de especialista; é preciso falar como mulher que pensa e quer pensar com os outros, para lá das disciplinas e das dicotomias, para lá das compartimentalizações e reduções; para lá dos egos auto-insuflados que buscam nichos que visibilidade quase imorais... Por isso, de onde deve a mulher, intelectual pública, falar?

Desse lugar que se constrói na crítica do espaço que ela mesma ocupa. O lugar da desconfiança, da suspeição, mas também o lugar que se faz ele mesmo a partir da questão e do confronto, da não aceitação, da rebelião, da resistência. O lugar que se cria por oposição ao que é errado e que se orienta por alguma ideia de justiça. A mulher enquanto intelectual pública deve criar e ocupar esse lugar: o lugar do não conformismo, o lugar da desobediência, inclusive, e talvez ainda mais importante hoje, da desobediência às ideologias que, por se tornarem tão dominantes se tornaram rígidas, inflexíveis, e por isso facilmente perigosas. Rousseau dizia que era preciso educar a mulher para a obediência e docilidade ${ }^{4}$, pois via nela, ou melhor, via em todas as mulheres o potencial da subversão e da irreverência. Ele sabia, como talvez tantos outros homens, que as mulheres não podem ser realmente controladas; que elas representam um perigo à ordem masculina. E ele estava certo. Porém, toda esta resistência tem de ser conjunta; toda esta denúncia tem de manifestar a união de muitas, uma união que guarda em si a pluralidade das experiências; toda esta crítica deve traduzir o movimento existencial, concreto, de mulheres reais que pensam em conjunto. A mulher, ou melhor, as mulheres enquanto intelectuais públicas no Brasil devem contribuir para refazer a própria 'esfera pública' e o que nela é incluído, isto é, devem contribuir para introduzir novas pautas e novas lutas e devem dar o exemplo, lutando contra a 'pseudo' cultura que nos prende numa cacofonia cada vez mais ampla e absorvente a cada dia que passa - se as mulheres, no seu papel de intelectuais públicas, derem o exemplo do questionamento das bandeiras e ideologias que inclusive elas mesmas levantaram num determinado momento da história, talvez se criem as condições para um novo horizonte de luta e de atribuição de sentido à nossa vida em comum.

\section{Referências}

\footnotetext{
${ }^{4}$ Ver Emílio.
} 
COSTA, M.

BEAUVOIR, S. O segundo sexo. Nova Fronteira, 2009.

COSTA, M. N. Ensaios no feminino. São Paulo: LiberArs, 2018.

GOUGES, O. Declaração dos direitos da mulher e da cidadã. 1791.

WOLLSTONECRAFT, M. Reivindicação dos direitos da mulher. São Paulo: Boitempo, 2018.

Submissão: 21.06.2019 / Aceite: 25.06.2019. 